\title{
A Comparison of Cultural Connotations between Chinese and English Animal Words
}

\author{
$\mathrm{Na} \mathrm{Li}$ \\ Zhenjiang Watercraft College, Zhenjiang, China \\ Email: nanalee8223@126.com \\ Yan Liu \\ Zhenjiang Watercraft College, Zhenjiang, China
}

\begin{abstract}
Throughout the history of the social evolution, man and animals come into frequent contact that forms an interdependent relationship between man and animals. The images of animals root in the everyday life of all nations, forming unique animal culture of each nation. Therefore, Chinese and English, as the two languages which spoken by the most people in the world, naturally contain a lot of words relating to animals, and because of different history and culture, the connotations of animal words in one language do not coincide with those in another. The clever use of animal words is by no means scarce in everyday communication or literary works, which helps make English and Chinese vivid and lively in image, plain and expressive in character, and rich and strong in flavor. In this study, many animal words are collected for the analysis of the similarities and the differences between the cultural connotations carried by animal words in Chinese and English, find out the causes of differences, and then discuss some methods and techniques for translating these animal words.
\end{abstract}

Index Terms - English and Chinese, animal words, figurative meaning

\section{INTRODUCTION}

It is well known that the Western culture originated in ancient Greek mythology and oriental culture with ancient Chinese culture as the mainstream are the two richest, most complete cultural systems on the earth, and they have widespread impact around the world. After thousands of years, these two cultural systems developed their own cultural characteristics. Carol R. Ember (2009), the American social linguist once said that language reflects the corresponding culture through vocabulary (p.45). Therefore words become a carrier of culture and attract much attention. There are many animal words in English and Chinese. According to the habits of animals, people often link those animal words with a specific character and identity, and therefore these words will remind people of the figurative meaning of a particular. Some animal words in Chinese and English are the same or similar in cultural connotations, because the Chinese people and the English people have some same capabilities of thought, some same laws of cognition, and some animals have the same important role in the human life of these two nations, and have the same attributes and features. But some of them are dissimilar or different. The cause of it is that the English people and the Chinese people are different in Aesthetic standards, history, geographical environment, custom, etc.. The key point of this paper is to explain and analyze the similarities, differences of cultural connotations in animal words used in English and Chinese basing on cultural linguistics and contrastive linguistics perspectives. Language is not only a component of culture, but also the carrier of culture. Learning language words is actually learning the culture. Therefore, it is very important and necessary for us to strengthen language culture learning, which is the key for improving the efficiency of vocabulary learning and approaching the real target of vocabulary teaching, thus afford us a full preparation for a better cross-cultural communication.

\section{A COMPARISON OF CULTURAL CONNOTATIONS OF ANIMAL WORDS IN CHINESE AND ENGLiSH}

Because of the influence of different cultural factors (such as history, customs, religions, values, etc) the cultural connotations of animal words are different in these two cultures. In the thesis, the similarities and differences between Chinese and English animal words are analyzed in four types. They are same object and same or similar figurative meaning; same object but different figurative meaning; same object but a vacancy of figurative meaning; different object but same or similar figurative meaning.

\section{A. Same Object with Same or Similar Figurative Meaning}

Different nations have different views to different objects, but all human beings have some similar capabilities of thought, some same laws of cognition, therefore, the people from both countries recognize animal from its basic quality that will certainly create the same or similar attributes. In different languages, some same animals will be endowed with the same or similar images. For example, "he is a fox", which means a very canning in Chinese. Therefore, it can be 
easily understood that fox is usually used to describe men's treacherous and tricky. In American slang, amazing and fashionable young lady is called fox, but with less derogatory sense in English. Besides, men never be enchanted by vixen, because people associate vixen to shrew or hot-tempered women. For instance, "having a vixenish temper". As English proverbs says, "when the fox preaches, take care of your geese", which warns us to guard against fox. Judging from the above examples, it can be seen clearly that different people have same impression on fox. Either in Chinese or English, the mice have negative meaning. For instance, we use the "dăn xiăo rú shǔ", "zéi méi shǔ yăn" to describe the cowardly, humble, short-sighted person in Chinese. In the United States slang, rat is the lowly and disloyal people. A rat crossing the street is chased by all. Wolf is a fierce and greedy animal in Chinese people's mind. There are "láng zǐ yě xīn", "láng bèi wéi jiān" in Chinese language. In English, there is also the statement "wolf dressed in sheep's clothing", pretending to describe a kind of people act friendly but in fact has evil intentions. Either in Chinese or English, the mice have negative meaning.

\section{B. Same Object but Different Figurative Meaning}

Because English and Chinese have the different language culture, different geographical environment, different cognitive feelings and ways of thinking, most animal words though refer to the same animals in Chinese and English have different figurative meanings. Cobuild Collins (1987) explained in his dictionary that "Dragon" is regarded as mythical monster, usually represented as a large reptile with wings and claws, breathing out fire and smoke. However, the explanation of dragon in the Chinese dictionary is a mythical animal in the Chinese legend, with scaly skin, claws and legs. It can fly and swim, and can create clouds and rain. Obviously, the major difference lies in the distinction between monster and mythical animal. In western culture, dragon is a symbol of monster without any good connotation. However, in the Chinese culture, dragon is not a symbol of nobleness and mystery, but also a metaphor referring to the emperor with supreme power. Undoubtedly, when the emperor is angry, Chinese people will have their say like "The emperor flew into rage", The offspring of the emperor are called "the offspring of dragon". As we all know, Chinese parents living out a fantasy that their children could be the dragon someday. An English man will feel stunned upon hearing, because from his view the Chinese parents expect their children to be nothing but a monster. In English, fierce and brutal women are called dragon. For instance, "she is a real dragon, you'd better keep away from her". If people intend to express Chinese concept of "dragon" in English, it will be better to interpret it into "Chinese dragon", in order to avoid the misunderstanding, "yà zhōu sì xiăo long" should be translated into "Four tigers" instead of "Four dragons". Dragon culture is the specialty of Chinese culture, and it embodies the specific character of national culture.

In Chinese sheep stands for people who are noble and charming, artistic and love nature. But in English, sheep, goat, ram are used to describe bad things. Sheep in English means "coy coward" and even "stupid people", goat can refer to a lecher, also can refer to a scapegoat, a victim; play or act the giddy goat "acts like a clown"; ram means a satyr. It is often happen that the same animal words in the English and Chinese culture have different figurative meanings. Another example: if you said to a Chinese: "You are a lucky dog." The listener may very unpleasant. "An old dog" in Chinese is a curse in saying that, while in English it means that "old, but experienced people." Cat in Chinese eyes is a kind of gentle sweet little animals, in many cases, the Chinese use cat to describe a person with the intimacy, such as "small slander cat". While in the Western culture, "cat" is the incarnation of Satan in the legend. The same sentence "she is a cat", English people will understand like: She is a spiteful or unpleasant woman, because the "cat" in English means "despicable woman", and Chinese people will think "She is a very lovable person".

\section{Different Object but Same or Similar Figurative Meaning}

Chen Wenbo (1982) once said that the English culture connotations of some animal words are the same or similar to the Chinese cultural connotations of other Chinese animal words. Their implied meanings are the same, but their names are different. This is a case that we often have in translation.

In Chinese, people take mouse as timid person. "as timid as a mouse" is employed to express cowardice, while English people use "as timid as a rabbit, chicken-hearted or pigeon-hearted" to deliver the same meaning, and rabbit, chicken, pigeon are used to express cowardice. China has a saying that "chū shēng niú dú bù pà hǔ", because the Chinese treat the tiger as the "king of beasts", is a symbol of bravery. While the foreigners treat the lion as the "king of beasts." For example, "as bold as a lion". If we only translate literally, the aliens can not be precisely understood the real meaning of the language. Such as the Lion's den that means a difficult situation in which you have to face a person or people who are aggressive towards you. Translated into Chinese is "lóng tán hǔ xué", which means in danger.

\section{Same Object but a Vacancy of Figurative Meaning}

Hornb A. S. (1997) said that in English, bull is used to describe the troublemaker and the person that acts rude, clumsy; chicken means a coward; eel implies cunning, dishonest, unreliable people, and so on. But in Chinese culture there is no such association. In Chinese we have the idiom "zhǐ lù wéi mă", but the equal expression in English is "talk black into white". The English version of the Chinese saying "guà yáng tóu mài gǒu ròu" is "to cry up wine and sell vinegar". 
Cultural connotation of some animal words in English and Chinese are closely related to the aesthetic standards, history, geographical environment, and the customs of a nation.

\section{A. Aesthetic Standards}

Aesthetic standards are the main reason for the appearance of animal words' different figurative meaning. Animals in different styles often used to describe the person or thing of a certain character, so that the expression is vivid, thus some animal words in different cultures have the same or similar figurative meaning. As in English culture, the dragon is a kind of cruel, violent reptile and without respect. It is a heinous monster, a symbol of the devil. In Chinese, the ancient Chinese have the supreme respect on dragon which is a mysterious animals in ancient legends of their own country. Dragon is not only a symbol of the emperor in feudal society, but also a symbol of the Chinese nation. Dragon, this word stands for the source of the Chinese culture of about five thousand years. It is a special product of the Chinese culture. The Chinese take proud of being "the descendants of dragon" while Western people can not understand it.

\section{B. History}

Nobility of ancient China called the ordinary people as "yimmín" (ant people), it means the low status of the ordinary people whose life is not valuable. However, in Western minds, the ant people are that the people who are brave and good at fight. This originated in ancient Greek mythology.

In Chinese, we will be faced with some words such as "qì zhuàng rú niú". Cattle and horses were good helpers of two nations' people in the production process, they left good impressions in the people's mind, and so have the above usage of words. Ancient Chinese people always use the cattle to plow the land, but the early British farming with the horse. If we want to express the same meaning we will use "works like a horse, as strong as a horse, flog a willing horse". In Chinese, "cattle" has the same meaning as the "horse" in English. That's caused by their different histories.

\section{Geographical Environment}

As we know, Britain is a typical island country. There are many aquaculture and boat-related words in English. The Chinese animal words about ocean and marine aquatics are fewer than Britain's. For example, in English "fish" has rich cultural connotation while in Chinese it doesn't. Such as "to have other fish to fry" means have nothing to do, fish in the airyuán mù qiú yú),an odd fish (guài rén), cool fish (hòu liăn pí), fresh fish (xīn qiú fàn) etc.. The reason is that in Britain fisheries and maritime industry plays an important role in economic life. Only the coastal areas in China have fishermen, so there are few of these words in Chinese language.

We can use oyster to describe a quiet person. It is said that the best oysters are produced in England, and the best oysters are always closed mouth tightly.

Beavers mainly live in North America. They build their nests with high techniques and inflexible will. People of American countries are familiar with this kind of animal. So in English "beaver" means "the people who work hard". As the geographical environments in China are quite different, the Chinese people hardly know this kind of animal and their special cultural connotations.

\section{Customs}

There are many differences between English customs and Chinese customs, the most typical of this is the attitude towards dogs. Dog in Chinese is a humble animal. Chinese idioms with dog are mostly derogatory: "hú péng gǒu dăng", "gǒu jí tiào qiáng", "láng xīn gǒu fèi” "gǒu tuǐ ž̌" and so on. Although in recent years, the number of people who raising pet dogs has increased dramatically, the dog's "status" seems to have changed, but the dog's derogatory image was deeply remained in the Chinese language culture. However, Du Xuezeng (1999) proposed that in western English-speaking countries, dogs are considered man's most loyal friend. English idioms with dogs in addition to the influence of other languages contain derogatory, most have no derogatory sense. English idioms often describe the person's behavior with the image of a dog's. You are a lucky dog (you're a lucky one), every dog has his day (each one has his lucky day), Old dog will not learn new tricks (the elderly can not learn new things) and so on. Described the man "seriously ill" with the sick as a dog, "very tired" is dog-tired

Owl in the West is the symbol of calm and intelligent. People often use a wise old owl to describe wise old man. Owls also often appear with the image of impartial judge. Because in ancient Greek mythology, the guardian goddess Athena is the goddess of wisdom and the trial, and her symbol was an owl. But in most parts of China, the owl which always issue shrill cry very late at night is considered to be an animal with bad luck. People thought hearing its sounds indicates that someone would be dead, and therefore, there is a Chinese saying "māo tóu yīng jiào xiào".

\section{Some Methods of Translating Animal WordS}

The purpose and characteristics of translation work are the communication of ideas and cultural. Different countries or different regions have the hope of mutual understanding between each other; have the wish to learn from each other. This makes the translation of animal words become a problem, which worthy of study either in theory or in practice.

\section{A. Literal Translation}

Literal translation refers to translate a sentence originally, keep the original message form, including construction of 
sentence, meaning of the original words, metaphor of the original and so on. Translation would be fluent and easy to comprehend by target language readers.

In translation, we can use literal translation when the same animals are endowed with the same or similar images both in Chinese and English. For example, a wolf in sheep's clothing is an analogy of one kind of people who may seem friendly, but in fact is the evil person like wolf. The sheep has a good, gentle symbolism and the wolf is extended for the cruel, dangerous people, so we can use the literal translation here. Another example, cock-a-hoop used to describe the pretentious, arrogant, rude people. With the development of modern technology, increasingly cultural exchanges, there is no need to comment the translation of some animal words. It is proved that the literal translation has accepted by readers, and enriches the language. In Chinese language culture, the rooster has a similar meaning, therefore it can be translated into "dé yì yáng yáng dì" or "ào dé xiàng zhī dà gōng jī”. For instance, crocodile tears may initially be translated as "jiă cí bēi" or "māo kū lăo shǔ". However, unconsciously, "crocodile tears" has been accepted by the Chinese readers. Dealing with the animal words in English, sometimes literal translation can be a good method.

However, in some cases, when translating we must take the cultural psychology, aesthetic custom, consumption habits and style concepts (such as text structure and style) into account. For example, the translation of the brand with animal words, it can prevent us from economic losses in international commercial activities.

Here are some examples, "bái yǔ" is a brand of pen, in Chinese, we have "jī máo xìn", "qiān lǐ sòng é máo" and other sayings with feathers. But in English idiom "to show the white feather" is "sneak away at a critical juncture", "weakness", and it has an insulting meaning. If translate "bái yǔ" into "WHITE FEATHER", the pen will not be accepted by foreign customers.

\section{B. Liberal Translation}

Liberal translation is also called free translation, which does not adhere strictly either to the literal meaning or the word order of the original. Sometimes the animal image just exists in the source language or in the target language, and does not exist in the target language or the source language at all. In this case, we can just translate the meaning of the original because the first purpose of translation is to convey the meaning. In English "to teach fish to swim" means that you are teaching someone who is more experienced than you, in Chinese we use "bān mén nòng fư" to describe the same meaning. There are some other examples, to run like a rabbit in Chinese means "yī liū yān de păo diào"; to swim like a duck could be translated into "shí shuǐ xìng"; one swallow does not make a spring means "yī zhī dú xiù bú shì chūn" in Chinese.

\section{Substitution}

Some animal words may have totally different or even opposite cultural connotations; this is the real problem in translation to deal with them. For these animal words, the translator can use the method of substitution. Such as: "talk horse" can be translated as "chū niú", the ancient Chinese people treat cattle as the most important animal, it is very common in everyday life. But in Western countries, people make the use of horsepower frequently, so horse is used there. Another example: a lion in the way can be translated as "lán lù hǔ" and "Rats desert a falling horse" can be translated as "shù dăo hú sūn sàn" and so on.

"To keep the wolf from the door" is very easily translated as "bú yào yǐn láng rù shì" while it's English meaning is to be able to buy enough food for oneself and one's family, as "néng gòu miăn yú jī è" "miăn qiáng kě yǐ wéi chí shēng huó" in Chinese, and has nothing to do with "y̌rn láng rù shi”, it must not be confused.

\section{Necessity to Study the Methods of Translating Animal Words}

To learn the methods of translating animal words between English and Chinese can provide practical guidance to understand the cultural differences, which is necessary in intercultural communication. It can help us to appreciate the two cultures further and remove the barriers in intercultural communication.

To learn the methods of translating animal words between English and Chinese can also prevent us from economic losses in international commercial activities. For example, a clock factory in China sells its product named "goat" to the western countries without knowing that "goat" in English refers to "unpleasant old man, especially one who is sexually active", no wonder there is no market for this product. Take "white elephant" for another example, "white elephant" in English means "clumsy and useless", therefore, battery named "white elephant" certainly couldn't make a profit in western market. From these examples we can find that different cultural connotations of animal words would cause misunderstandings.

\section{CONCLUSION}

This paper mainly analyzes the connotations of culture on animal words and then helps us to realize the cultural differences between English and Chinese. The causing and developing of different words' connotations are closely related to the history backgrounds, geographical environment, custom habits, aesthetic standard. It reflects cultural diversities between two nations. These cultural information is accumulation and ideological essence of laboring people, that comes from a long course of human's social practicing and living.

Knowing about these similarities and differences will help us to convey the right information in translation and 
multicultural communication. This paper also analyzes the causes of the discrepancy between cultural connotations between these two languages' animal word. Those cultural connotations are not only inspire human's endless imagination, but also give the words more extensive meanings. What's more, cultural connotations possess specific cultural enchantment and irreplaceable power of expression.

By means of contrastive analysis for animal word's cultural connotation, we can understand very clearly that animal words are not only a symbol of animal figures. Because animal words were deeply marked by cultural diversity, so it was given varied cultural connotations.

We should pay more attention to the cultural connotations of animal words of the two languages, so we can translate properly from the source language into the target language.

In order to master vocabulary, we should study hard on understanding word's connotations. Therefore, we must insist on reading large number of articles and learning cultural connotations to help us to understand much better. Only understanding the cultural traditions and custom habits, can we communicate with others smoothly and achieve a cross cultural communication.

\section{REFERENCES}

[1] A New Century Chinese-English Dictionary Foreign. Language Teaching and Research Press. (2005).

[2] Carol R. Ember. (2009). Cross-Cultural Research Methods. New York:Altamira Press.

[3] Chen Wenbo. (1982). English and Chinese Idioms. Beijing: Foreign Language Teaching and Research Press.

[4] Cobuild Collins. (1987). Collins Cobuild English Language Dictionary. London: London and Glasgow.

[5] Du Xuezeng. (1999). Comparison between Chinese and English Cultural Conventions. Beijing: Foreign Language Teaching and Research Press.

[6] Hornb A. S. (1997). Oxford Advanced Learner's English-Chinese Dictionary (4th edn). England: Commercial Press and Oxford University Press.

[7] Oxford Advanced Learner's English-Chinese Dictionary (Sixth Edition). Oxford University Press. (June, 2004).

Na Li was born in Zhenjiang, Jiangsu, China in 1982. She received her bachelor. degree in linguistics from Guilin Industrial College China in 2006. She has been teaching English for 4years in Watercraft College, Zhenjiang. Her research interests include English Linguistic and Literature Translation.

Yan Liu was born in Zhenjiang, Jiangsu, China in 1979. She received her master degree in linguistics from Katholieke University Leuven in 2006. She has been teaching English for 5 years in Watercraft College, Zhenjiang. Her research interests include psycholinguistics and American literature. 